\title{
SOSIALISASI DESA SEHAT PADA KARANG TARUNA
}

\author{
Herman Lawelai ${ }^{1}$, Asrin ${ }^{2}$, Nurlinda ${ }^{3}$, La Yanto ${ }^{4}$ \\ ${ }^{1}$ Dosen Program Studi Ilmu Pemerintahan Fakultas Ilmu Sosial dan Ilmu Politik \\ ${ }^{234}$ Mahasiswa Program Studi Ilmu Pemerintahan Fakultas Ilmu Sosial dan Ilmu Politik \\ Universitas Muhammadiyah Buton. \\ Email: hermanlawelai@yahoo.com
}

\section{Submitted: 12 Agustus 2020 Accepted:18 April 2021 Published: 30 April 2021}

\begin{abstract}
Abstrak: Sampah dan kebersihan adalah sesuatu yang tidak dapat dipisahkan. Desa bersih dan sehat merupakan langkah yang harus dilakukan untuk mencapai derajat kesehatan yang optimal bagi setiap orang yang tinggal di dalamnya. Kondisi sehat tidak serta merta terjadi, tetapi harus senantiasa diupayakan dari yang tidak sehat menjadi hidup yang sehat serta menciptakan lingkungan yang sehat. Upaya ini harus dimulai dari menanamkan pola pikir sehat kepada masyarakat melalui Karang Taruna. Upaya ini adalah untuk mewujudkan derajat kesehatan masyarakat seting-gitingginya sebagai satu investasi bagi pembangunan sumber daya manusia yang produktif. Pendekatan yang dilakukan melalui kampanye bersama dan aksi pungut sampah sebagai sarana edukasi bersama. Program kegiatan ini betujuan untuk mensosialisasikan kebersihan kepada masyarakat, harapannya kesadaran masyarakat akan kesehatan dan pola hidup bersih dan sehat meningkat. Untuk itu pemberian sosialisasi terkait desa sehat diharapkan dapat menjadi upaya menyadarkan masyarakat akan pentingnya melakukan upaya perilaku hidup bersih dan sehat dalam kehidupan sehari-hari sekaligus memberikan pengetahuan bagaimana cara merealisasikannya sehingga bisa terwujud masyarakat yang peduli sehat.
\end{abstract}

Kata kunci: Desa Sehat, Masyarakat Peduli Sehat, Kampanye Kebersihan 


\section{PENDAHULUAN}

Derajat kesehatan dipengaruhi oleh 4 faktor yaitu faktor lingkungan, faktor perilaku, faktor keturunan dan faktor pelayanan kesehatan. Dari keempat faktor tersebut, faktor kedua, yaitu faktor perilaku sangat berpengaruh dalam kesehatan seseorang, terutama dalam penerapan PHBS (Perilaku Hidup Bersih dan Sehat) baik dilingkungan pribadi, keluarga, maupun masyarakat (Andriansyah \& Rahmantari, 2013). Keadaan sehat adalah kehendak semua pihak, tidak hanya di dominasi oleh perorangan, akan tetapi juga harus dimiliki oleh kelompok dan bahkan oleh masyarakat.

Desa yang bersih menjadi sebuah cerminan bagi setiap individu dalam menjaga kesehatan jasmani dalam kehidupan sehari-hari. Sebagaimana diketahui bahwa kehidupan manusia sendiri tidak bisa dipisahkan baik lingkungan alam maupun lingkungan sosial. Maka seharusnya segala aspek yang ada dalam masyarakat dapat menjaga kebersihan lingkungan. Karena tanpa lingkungan yang bersih, setiap individu maupun masyarakat akan menderita sebab sebuah faktor yang merugikan seperti kesehatan.

Kesehatan itu begitu mahal harganya. Sehingga semuanya harus diolah dengan baik. Desa yang kotor berarti penganggu kesehatan, yang juga berarti membuat bibit penyakit. Namun segala sesuatu pasti bisa ada perubahan hanya saja dalam segala persoalan-persoalan, semua ini tidak dapat dijalankan tanpa sebuah kesadaran dari masyarakat serta peran pemerintah untuk menjaga kebersihan, maka kebersihan itu tidak akan berguna dan menimbulkan banyak kerugian kalau semua pihak tidak ikut terlibat.

Meningkatnya jumlah sampah dapat disebabkan oleh berbagai faktor, salah satunya adalah pertambahan penduduk. Semakin bertambahnya jumlah penduduk, maka kebutuhan pokok seperti sandang dan pangan pun akan bertambah, hal tersebut tentunya akan menyebabkan peningkatan jumlah sampah yang dihasilkan. Faktor lainnya adalah ketersediaan fasilitas pendukung kebersihan, misalnya tempat sampah atau tempat pembakaran sampah. Jika fasilitas pendukung kebersihan tersedia, masyarakat dapat dengan segera menangani sampah yang ada. Sebaliknya, jika fasilitas pendukung tidak tersedia, masyarakat dapat terhambat dalam proses menangani sampah (Rasmini, 2018).

Kesadaran masyarakat terhadap lingkungan sangatlah minim, berdasarkan hal tersebut dapat diprediksi bahwa 
masyarakat masih belum peduli terhadap kebersihan lingkungan sekitarnya. Kebanyakan dari masyarakat berfikir secara parsial dan hanya ingin menguntungkan diri sendiri, seperti masalah pembuangan sampah yang tidak pada tempatnya, pembuangan limbah rumah tangga dan lainlain. Kasus-kasus yang menyangkut masalah kebersihan setiap tahunnya selalu meningkat, dan mengakibatkan keadaan yang merugikan seperti banyaknya sampah yang menumpuk di titik-titik tertentu dan saluran air yang bisa menyebabkan banjir karena meluapnya air yang tidak tertampung, untuk itu kepedulian masyarakat sangat dibutuhkan tidak hanya pemerintah setempat yang harus menanggungnya.

Desa Bahari Kecamatan Sampolawa Kabupaten Buton Selatan berlokasi di daerah pesisir pantai. masih ditemukan lingkungan yang kotor yang tersebar di beberapa titik, paling sering dijumpai adalah sampah rumah tangga yang banyak dibiarkan di pinggir dan di depan rumah, juga di jalan-jalan, banyak sampah berserakan yang tidak dikelola dengan baik oleh masyarakat, penyebabnya belum tersedianya tempat pembuangan sampah, terlebih apabila musim penghujan, banyak sampah yang terseret air memenuhi jalan,
Saluran drainase yang kotor akibat sampah dapat mengakibatkan banjir.

Kesadaran masyarakat dalam hal ini menjadi penting, karena kesadaran masyarakat adalah proses yang diawali dari adanya rasa memiliki, yaitu rasa memiliki lingkungan sekitar yang akan memicu rasa tanggung jawab. Rasa tanggung jawab ini akan menghasilkan kesadaran warga bahwa tugas untuk menjaga lingkungan bukan hanya kewajiban pemerintah saja tapi juga warganya.

Kondisi sehat tidak serta merta terjadi, tetapi harus senantiasa diupayakan dari yang tidak sehat menjadi hidup yang sehat serta menciptakan lingkungan yang sehat. Upaya ini harus dimulai dari menanamkan pola pikir sehat kepada masyarakat yang harus dimulai dan diusahakan oleh diri sendiri (Andriansyah \& Rahmantari, 2013).

Kurangnya kesadaran akan dampak dari lingkungan yang kotor sangat dipengaruhi oleh pengetahuan masyarakat. Dalam sejumlah observasi yang dilakukan dapat disimpulkan beberapa masalah pokok yang menjadi masalah di Desa Bahari, yakni sebagai berikut:

1. Belum optimalnya pengetahuan masyarakat mengenai pentingnya Lingkungan yang sehat. 
2. Belum optimalnya sosialisasi kepada masyarakat perihal bagaimana menciptakan dan meningkatkan lingkungan yang sehat.

Melalui organisasi karang taruna upaya untuk mewujudkan derajat kesehatan masyarakat setinggi-tingginya sebagai satu investasi bagi pembangunan sumber daya manusia yang produktif. Dalam mengupayakan perilaku ini dibutuhkan komitmen bersama-sama saling mendukung dalam meningkatkan derajat kesehatan masyarakat khususnya keluarga sehingga pembangunan kesehatan dapat tercapai maksimal.

Sosialisasi dilaksanakan untuk menumbuhkan kesadaran tanggungjawab sosial generasi muda Karang Taruna dalam mencegah, menangkal, menanggulangi dan mengantisipasi berbagai masalah sosial di ligkungannya.

Adapun tujuan Sosialisasi Desa Sehat Pada Karang Taruna adalah sebagai berikut:

1. Organisasi karang taruna menajdi penggerak untuk menciptakan lingkungan sehat.

\section{Meningkatnya} kesadaran masyarakat perihal menjaga kebersihan.
3. Melakukan kampanye komunikasi kebersihan dalam bentuk pungut sampah.

\section{METODE PENELITIAN}

Mitra dari kegiatan pengabdian kepada masyarakat ini yaitu Karang Taruna Desa Bahari Kecamatan Sampolawa Kabupaten Buton Selatan. Peserta kegiatan dalam Sosialisasi Desa Sehat adalah diberikan sosialisasi meliputi tentang bahaya lingkungan yang kotor dan mafaat lingkungan yang bersih.

Tahapan kegiatan PKM tentang sosialisasi desa sehat pada karang taruna desa bahari adalah:

1. Survey dan Penetapan Wilayah Mitra

2. Pelaksanaan kegiatan sosialisasi tentang desa sehat yaitu bahaya lingkungan yang kotor dan manfaat lingkungan yang bersih.

3. Pendampingan dalam bentuk kampanye kebersihan dan gerakan pungut sampah.

\section{HASIL DAN PEMBAHASAN}

Desa sehat adalah suatu upaya untuk menyehatkan kondisi pedesaan yang bersih, nyaman, aman dan sehat untuk dihuni warganya dengan mengoptimalkan potensi 
masyarakat, melalui pemberdayaan kelompok kerja masyarakat, difasilitasi oleh sektor terkait dan sinkron dengan perencanaan wilayah.

\section{Kegiatan pengabdian kepada} masyarakat kali ini adalah bagaimana meningkatkan pengetahuan karang taruna dalam menciptakan kondisi desa yang sehat. Penjelasan tahapan Kegiatan Pengabdian Kepada Masyarakat (PKM) yang dilakukan TIM PKM adalah sebagai berikut:

\section{Survey dan Penetapan Wilayah Mitra} Tujuan umum melakukan survey lapangan adalah untuk mengamati secara langsung lokasi wilayah mitra. Kegiatan pengamatan dilakukan guna menggali dan mengumpulkan data yang diperlukan bagi topik pembahasan guna pengembangan wawasan dan peningkatan bagi para peserta PKM. Tujuan survei lapangan adalah agar memahami tentang pengumpulan data/informasi, dapat mengetahui cara mengumpulkan data/informasi. Survei lapangan dilakukan secara kelompok.

\section{Pelaksanaan Kegiatan Sosialisasi tentang Desa Sehat}

Tahap sosialisasi program desa sehat dilaksanakan di balai pertemuan Desa Bahari, pertemuan dihadiri oleh kepala
Desa, dan anggota Karang Taruna Desa Bahari.

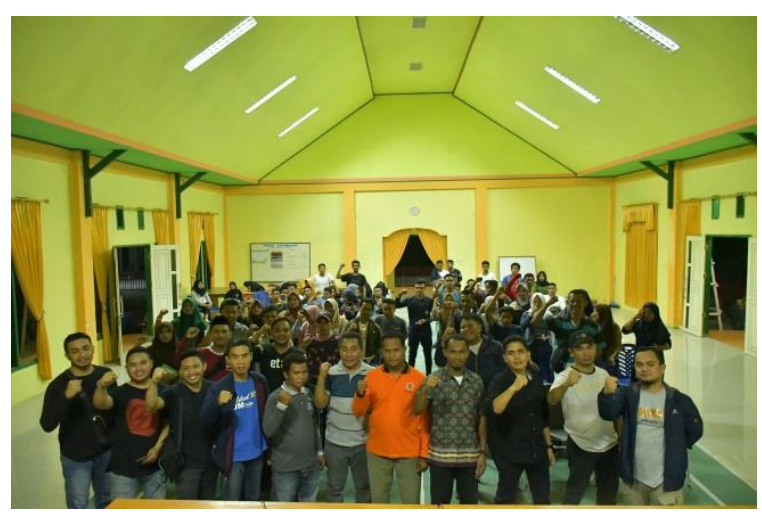

Gambar 1. Sosialisasi Desa Sehat

Sosialisasi tentang Desa Sehat yaitu stop buang sampah tidak pada tempatnya. Kemudian pada tahap sosialisasi diberikan pemahaman tentang efek samping dari buang sampah sembarangan/ tidak pada tempatnya dapat menimbulkan bau yang tak sedap untuk dihirup, menyebabkan wabah penyakit yaitu diare serta dapat menimbulkan banjir yang diakibatkan oleh tersumbatnya saluran drainase.

\section{Pendampingan dalam bentuk kampanye kebersihan dan gerakan pungut sampah.}

Kebersihan lingkungan mempunyai peranan yang sangat penting dan tak terpisahkan dalam kehidupan manusia. Menjaga kebersihan lingkungan sama artinya menciptakan lingkungan yang sehat, bebas dari kotoran, seperti debu, sampah, dan bau 
yang tidak sedap. Dengan lingkungan yang sehat, kita tidak akan mudah terserang berbagai penyakit seperti demam berdarah, malaria, muntaber, dan lainnya. Tidak hanya di bidang kesehatan, kebersihan lingkungan juga sangat berpengaruh terhadap kenyamanan, keindahan, dan keasrian lingkungan yang nantinya bermuara pada kedamaian. Semua ini dapat kita raih dengan melakukan perbuatan kecil dan sederhana, mulai dari menjaga kebersihan lingkungan di sekitar kita.

Kebersihan lingkungan dimulai dari lingkungan rumah dan tempat kita bekerja. Untuk kebersihan lingkungan di sekitar rumah, kita lakukan dengan membersihkan halaman dan telajakan rumah. Mari biasakan diri dengan pola hidup bersih. Sampah yang dihasilkan rumah tangga selanjutnya kita pilah menjadi tiga, yaitu sampah organik, sampah non-organik dan sampah botol atau pecah belah. Kampanye pemilahan jenis sampah ini akan sangat bermanfaat. Sampah organik bisa kita jadikan kompos sehingga bermanfaat untuk menyuburkan tanah dan tanaman. Sampah non-organik kita kumpulkan dan kita jual ke pengepul untuk didaur ulang sehingga memberikan nilai lebih. Sementara itu, untuk tempat kerja, ciptakan suasana ruang kerja yang bersih, rapi dan indah sehingga kita nyaman dalam melakukan aktivitas pekerjaan sehari-hari. Perlu juga diatur jadwal untuk kegiatan kerja bakti membersihkan lingkungan desa.

Penggunaan media kampanye adalah leaflet yang menyampaikan tentang Mari Kita Jaga Lingkungan mulai dari kebersihan lingkungan di sekitar kita.

Kampanye menjadi salah satu sarana pendekatan yang dirasa cukup bisa membantu dalam meningkatkan kesadaran masyarakat untuk menjaga kebersihan lingkungan. Melalui kampanye juga diyakini dapat memberikan perubahan pada sikap masyarakat (Permassanty, T. D., Tangkilisan, H. R., \& Zufri, 2015),

Seperti kata pepatah bersih pangkal sehat (gambar 2) merupakan bentuk kampanye yang dibagikan kepada masyarakat Desa Bahari oleh Tim PKM dan Karang Taruna Desa Bahari. Selain itu, kampanye juga dilakukan menggunakan pemasangan spanduk Kebersihan lingkungan adalah tanggung jawab kita bersama (gambar 2) pada beberapa lokasi di desa Bahari.

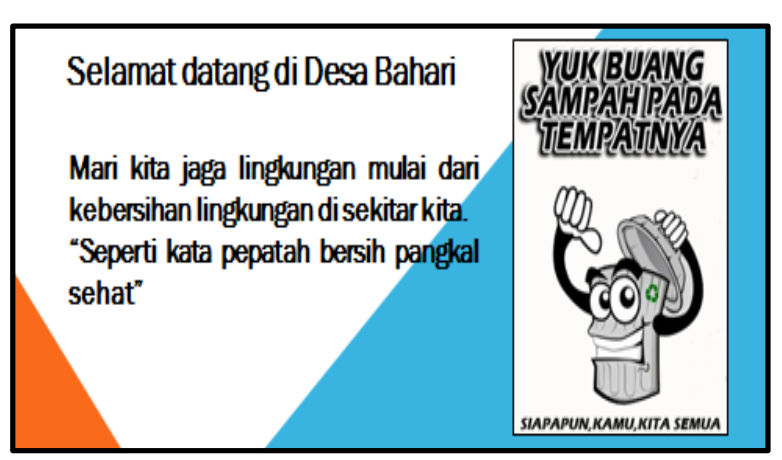




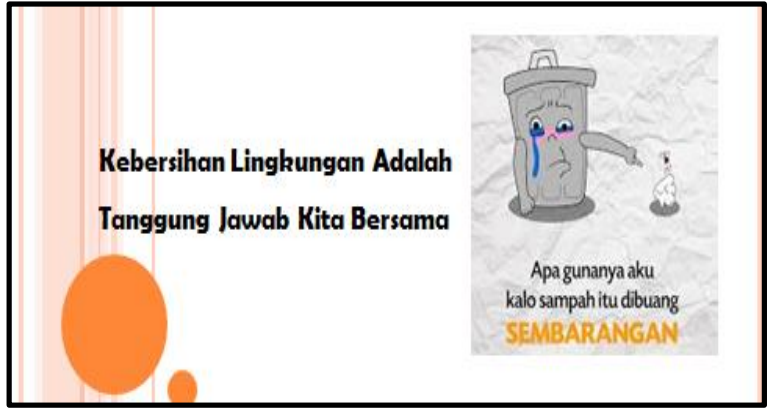

Gambar 2. Leaflet dan Spanduk Kampanye Kebersihan

Penggunaan media tersebut dalam kegiatan ini dianggap paling relevan untuk lebih mendekatkan metode kampanye kepada masyarakat. Disamping itu, dibuat dengan desain yang lebih mudah dikenali dan menarik untuk setiap lapisan umur.

\section{Gerakan Pungut Sampah.}

Gerakan Pungut Sampah adalah gerakan memungut sampah yang tercecer atau berserakan dengan tujuan mengajak warga untuk tidak membuang sampah sembarangan. Dalam tahap ini, kegiatan difokuskan pada aksi bersama pungut sampah yang dilakukan oleh tim PKM dan Karang Taruna Desa Bahari.

Mengajak warga untuk tidak membuang sampah sembarangan memerlukan kesabaran dan penyampainya harus menyenangkan. Tim PKM dan Karang Taruna Desa Bahari yang disebar di lingkungan Desa Bahari, untuk secara serentak memunguti sampah sambil berjalan menyusuri Desa Bahari. Peralatan yang digunakan dalam kegiatan ini adalah kantong sampah, yang dibawa untuk diisikan sampah hasil dipungut.

Maka dalam kegiatan ini, diikuti dengan melakukan kampanye melalui flyer dan spanduk yang dipasang pada beberapa tempat. Harapannya, dengan begitu kegiatan ini memberikan dokumentasi kepada masyarakat dan pengunjung untuk kembali meningatkan kesadaran bersama tentang pentingnya membuang sampah pada tempatnya.

\section{KESIMPULAN}

Melaui kegiatan PKM ini Organisasi karang taruna menjadi penggerak untuk menciptakan lingkungan sehat di Desa Bahari, dengan peran yang dilakukan oleh Karang Taruna dalam program Desa Sehat menumbuh kembangkan kesadaran masyarakat perihal menjaga kebersihan lingkungan.

Melakukan kampanye kebersihan dan aksi pungut sampah dengan tujuan adanya kesadaran kepada masyarakat Desa Bahari dalam menerapkan hidup sehat di lingkungan Desa Bahari dengan membuang sampah pada tempatnya. 


\section{DAFTAR PUSTAKA}

Andriansyah, Y., \& Rahmantari, D. N. (2013). Penyuluhan Dan Praktik Phbs ( Perilaku Hidup Bersih. Inovasi Dan Kewirausahaan, 2(1), 45-50.

Permassanty, T. D., Tangkilisan, H. R., \& Zufri, T. (2015). PERAN KOMUNIKASI DALAM KAMPANYE PUBLIK: EVALUASI PELAKSANAAN KAMPANYE TOL TANPA SAMPAH DI GERBANG TOL KARANG TENGAH. Avant Garde, 3(1), 71-82.

Rasmini, M. (2018). Program Lingkungan Sehat Bebas Sampah Pada Rw 10. Jurnal Penelitian Dan PKM, 5(April), hlm.1-5. 